\title{
Quality Enhancement of Producer Gas From Cassava Rhizome Using High Temperature Air-Steam Downdraft Gasification
}

\author{
Worapot Ngamchompoo and Kittichai Triratanasirichai \\ Department of Mechanical Engineering, Faculty of Engineering, \\ Khon Kaen University,123 Mittraparb Road, Muang, Khon Kaen 40002, Thailand
}

Received 2012-11-28, Revised 2013-03-06; Accepted 2013-05-08

\begin{abstract}
High Temperature Air-Steam Gasification (HTAG) was performed on a bench-scale downdraft gasifier. A cassava rhizome was used as feedstock for the gasification. Air and steam were utilized as the gasifying agents. The objectives in this study were to study the potential of HTAG technology applied with a downdraft gasifier to improve producer gas quality in terms of Higher Heating Value (HHV) and lower tar content. The results were compared with conventional air-steam gasification (without preheating). The results were that the HHV of the producer gas from the HTAG process at $900^{\circ} \mathrm{C}$ improved by as much as $5.1 \mathrm{MJ} / \mathrm{Nm}^{3}$ (at $\mathrm{S} / \mathrm{B}$ ratio $=0.3$ ), while the air-steam gasification, HTAG at $300^{\circ} \mathrm{C}$ and $\mathrm{HTAG}$ at $600^{\circ} \mathrm{C}$ couldonly obtain a $\mathrm{HHV}$ of $3.8 \mathrm{MJ} / \mathrm{Nm}^{3}$ (at $\left.\mathrm{S} / \mathrm{B}=0.4\right), 4.2 \mathrm{MJ} / \mathrm{Nm}^{3}$ (at S/B $=$ 0.1 ) and $4.8 \mathrm{MJ} / \mathrm{Nm}^{3}$ (at $\mathrm{S} / \mathrm{B}=0.2$ ), respectively. In addition, tar content in the producer gas of the HTAG process at $900^{\circ} \mathrm{C}$ had the lowest value $\left(95 \mathrm{mg} / \mathrm{m}^{3}\right)$ which could be used as fuel in an internal combustion engine. While the minimum tar content of the air-steam gasification was $320 \mathrm{mg} / \mathrm{m}^{3}$. In the HTAG process at $900^{\circ} \mathrm{C}$, the maximum Cold Gas Efficiency (CGE) was $65 \%$, which was slightly lower than the CGE of air-steam gasification (69\%). However, in the HTAG process at 300,600 and $900^{\circ} \mathrm{C}$ the maximum Hot Gas Efficiency (HGE) increased 33\% (from 72 to 96\%), 25 (from 72 to 90\%) and 7 (from 72 to $77 \%$ ), respectively; when compared with air-steam gasification.
\end{abstract}

Keywords: Downdraft Gasifier, Cassava Rhizome, High Temperature Air-Steam Gasification (HTAG)

\section{INTRODUCTION}

The cassava rhizome is located between the stalk and root of the cassava plant (Fig. 1). It becomes a residue left from the cassava plant when it is burnt in preparation for next seasons planting. Burning the crop residue from a field or from part of a field can cause smoke and impact the environment; moreover, there is no benefit from the potential use of agriculture wastes.

Researchers have reported that cassava production in Thailand is about 25 million tons per year (Atong et al., 2011) and about 8-10 million tons are made up of the rhizome. Therefore, the potential conversion of the cassava rhizome into renewable energy could be substantial. Biomass gasification is a series of thermo- chemical processes which can convert solid biomass into combustible gases called syn gas or producer gas. The main compositions of producer gas are $\mathrm{H}_{2}, \mathrm{CO}, \mathrm{CH}_{4}$ and $\mathrm{CO}_{2}$. High quality producer gas can be used as fuel in the Internal Combustion Engine (ICE) for producing electricity. High Temperature Air-steam Gasification (HTAG) technology has previously been developed (Lucas et al., 2004; Tsuji et al., 2002), this technology was discovered that using air and mixtures of air and steam preheated to high temperature $\left(300-1000^{\circ} \mathrm{C}\right)$ as gasifying agent for biomass gasification process can increase the quality of producer gas. This is because sensible heat from preheating can be utilized to replace partial heat which is produced by biomass combustion and can support the endothermic gasification reaction.

Corresponding Author: Kittichai Triratanasirichai, Department of Mechanical Engineering, Faculty of Engineering, KhonKaen University, 123 Mittraparb Road, Muang, Khon Kaen 40002, Thailand 


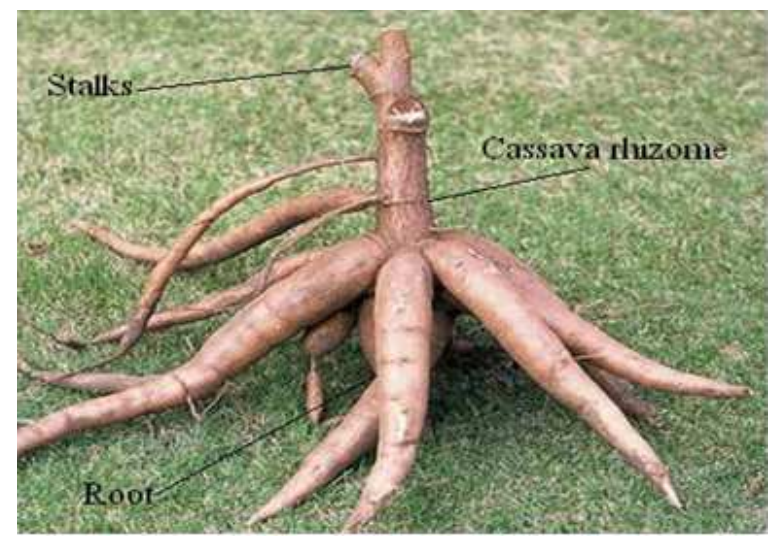

Fig. 1. Cassava rhizome

As a result, the air quantity for combustion decreases extremely, the nitrogen content in the product gas decreases and concentration of combustible gas in the product gas increases. Thus, high heating value and gas yield of the product gas are improved. HTAG technology has been studied with various types of gasifiers, such as the updraft gasifier (Lucas et al., 2004; Umeki et al., 2010), the entrain flow gasifier (Kobayashi et al., 2009) and the peddle bed gasifier (Pian and Yoshikawa, 2001); however, there has not been any study of HTAG integrated with the downdraft gasifier. The downdraft gasifier has shown an advantage in producing syn gas, low tar content and is easy to design and construct when compared to fluidized bed gasification systems. Moreover, producer gas from the downdraft gasifier has higher temperatures which can be used as recovery heat to preheat gasifying agents (Lv et al., 2007). The objective of this study is to enhance producer gas quality from the cassava rhizome in terms of HHV and lower tar content for ICE application by using HTAG technology. In this study, the downdraft gasifier will be used as a reactor. The results of the HTAG process will be compared to the conventional air-steam gasification process (without preheating). The expectations of this study are to find the potential of HTAG technology when applied with the downdraft gasifier to improve the gas quality and the gasification efficiency from the cassava rhizome.

\section{MATERIALS AND METHODS}

\subsection{Feedstock Materials}

The feedstock used in this experiment was the cassava rhizome (Fig. 2). Its bulk density was measured and found to be $281 \mathrm{~kg} / \mathrm{m}^{3}$. The proximate and ultimate analysis of the feed stock is shown in Table 1.

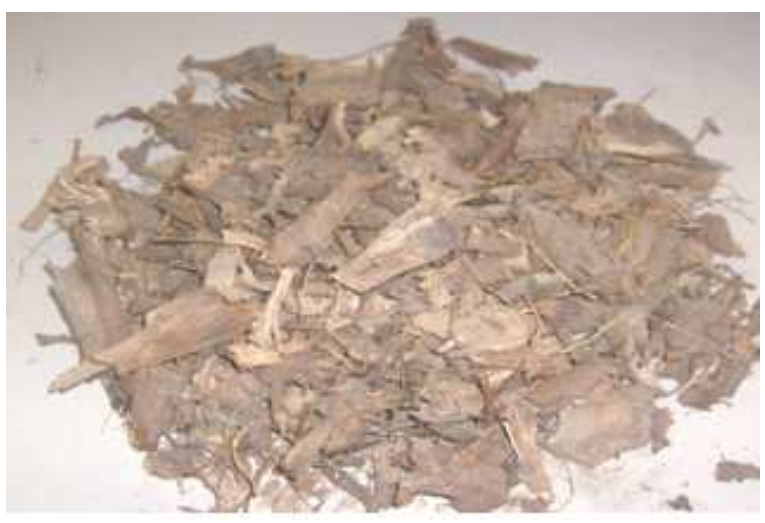

Fig. 2. Cassava rhizome after grinding

Table 1. Proximate and ultimate analysis of the cassava rhizome Proximate analysis (\% wt)

\begin{tabular}{lr}
\hline Ash & 2.27 \\
Moisture & 13.04 \\
Volatile matter & 78.06 \\
Fixed carbon & 13.12 \\
Higher heating value $(\mathrm{MJ} / \mathrm{kg})$ & 14.87 \\
Ultimate analysis $(\% \mathrm{wt})$ & \\
Carbon & 41.86 \\
Hydrogen & 6.48 \\
Nitrogen & 0.75 \\
Sulfur & 0.00 \\
Oxygen & 48.12 \\
\hline
\end{tabular}

\subsection{Experimental Set Up}

The gasification system consists of five main units: downdraft gasifier, preheater, steam generator, air blower and cyclone separator. The schematic diagram of the high temperature air-steam gasification system is shown in Fig. 3.

The downdraft gasifier reactor was cylindrical in shape with a $40 \mathrm{~cm}$ diameter and a height of $150 \mathrm{~cm}$. Six nozzles were installed in the combustion zone $20 \mathrm{~cm}$ away from the gate (Fig. 4). The diameter of the drying zone and the reduction zone were 30 and 20 $\mathrm{cm}$, respectively. At the bottom of the reduction zone, a gate was installed to support the charcoal from the pyrolysis process. Steam at atmospheric pressure was generated by the steam generator (Fig. 3). The steam generator was made of stainless steel of cylindrical shape and the heater was installed at the bottom of the steam generator. The flow rate of the steam which was controlled by peristaltic pump in the ranges 1, 2, 4 and $6 \mathrm{kgh}^{-1}$ were studied. A blower was used to provide air for gasification process. 


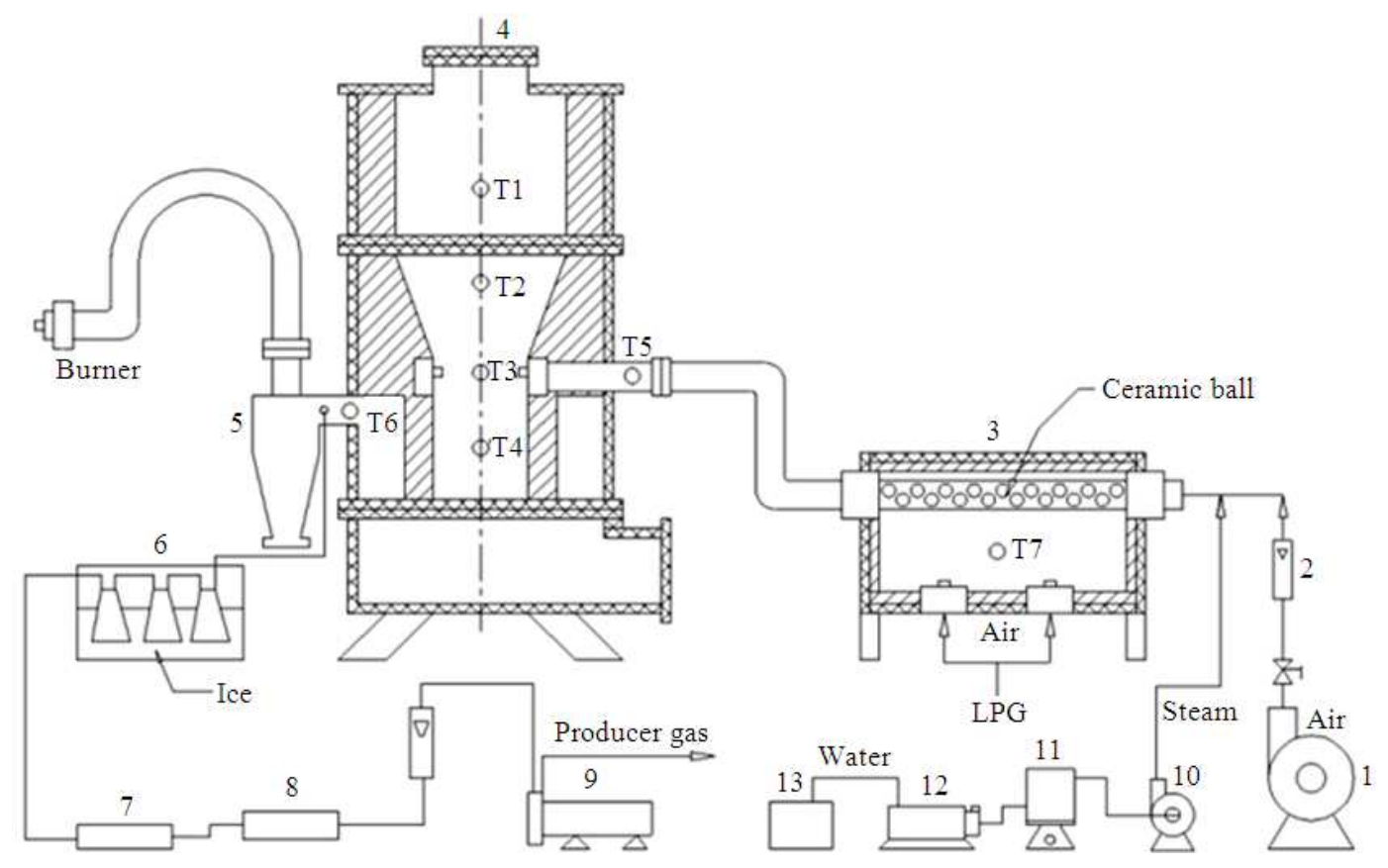

Fig. 3. Schematic of high temperature air-steam gasification, The numeral meaning: (1) Air blower; (2) Rotameter; (3) Preheater; (4) Downdraft gasifier; (5) Cyclone separator; (6) Tar sampling; (7) Filter; (8) Gas collector; (9) Vacuum pump; (10) Steam pump; (11) Steam generator; (12) Peristaltic pump; (13) Water tank

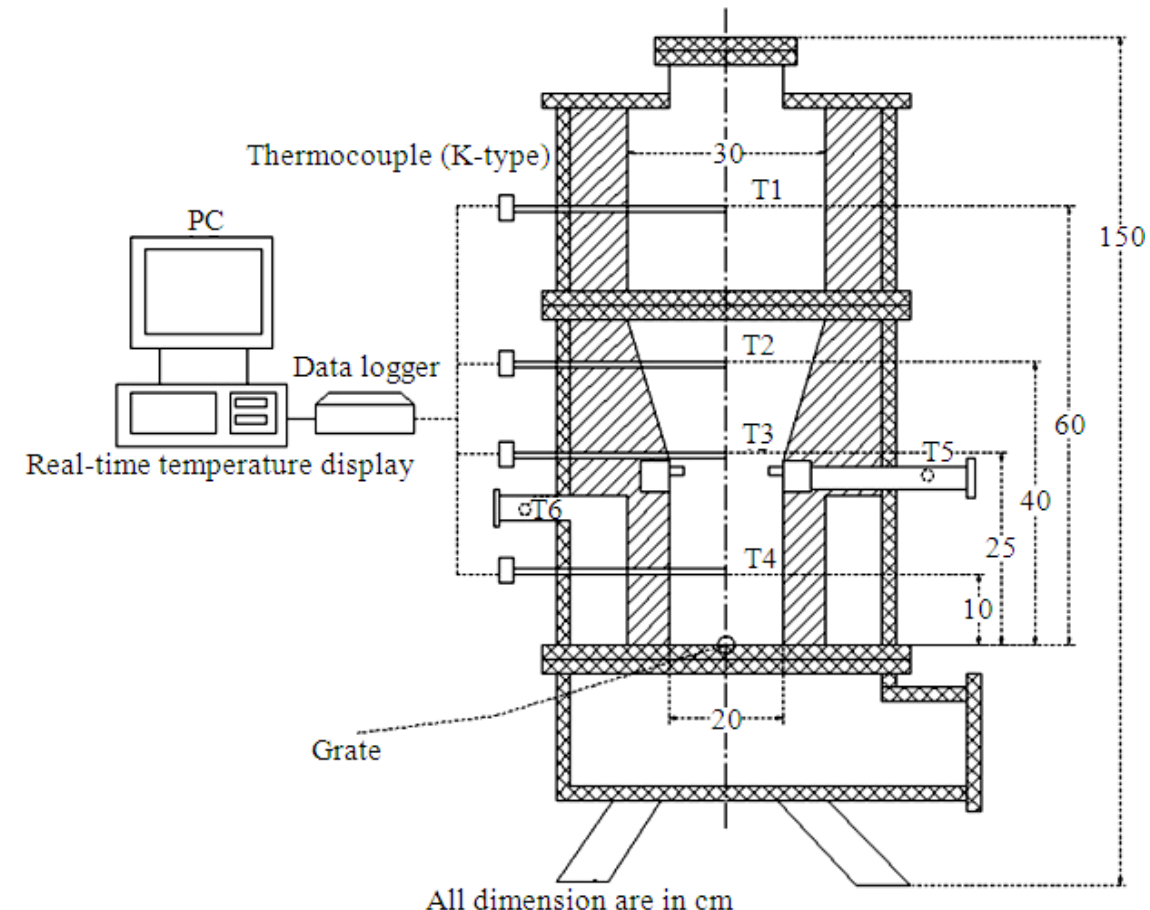

Fig. 4. Schematic of the downdraft gasifier and location ofthermocouples 
Air flow rate was controlled by valve and rotameter and varied at 100, 200 and $300 \mathrm{lpm}$, respectively. In this study, the regenerative preheater used a ceramic ball for heat storage, this material transferred heat to the gasifying agent (air mixed with steam). Many researchers (Lucas et al., 2004; Pian and Yoshikawa, 2001) have applied this preheater concept as well because the temperature of the gasifying agent can be increased to $1200^{\circ} \mathrm{C}$ (depending on the heat storage properties). The preheating temperature can be raised by adjusting the quantity of LPG gas and air through the burner. In this study, gasifying agent was preheated in the range of temperature 300,600 and $900^{\circ} \mathrm{C}$, respectively.

\subsection{Measurements System}

At the steady state condition, producer gas was sampled (by the gas collector) and the gas composition was analyzed. The main gas composition $\left(\mathrm{CO}_{2}, \mathrm{H}_{2}, \mathrm{CO}\right.$ and $\left.\mathrm{CH}_{4}\right)$ was detected by gas chromatogram (Shimadzu GC-2014) provided with a Thermal Conductivity Detector (TDC), connected with unibeads $\mathrm{C}$ column. Argon gas was chosen as the carrier gas in all analyses. Cold trapping was used as a tar measurements unit which consisted of six glass bottles soaked in an ice bath $\left(-15^{\circ} \mathrm{C}\right)$. Initially, sampling gas flow into the bottle after that the contaminated tar in the sampling gas was condensed. Then the tar content was measured and compared with the flow rate of sampling gas in $\mathrm{mg} / \mathrm{m}^{3}$ units. The temperature profiles along the gasifier vertical axis were measured by thermocouple (K-type, Chromel-Alumel) as illustrated in Fig. 4. The temperature of the drying zone (T1) was measured at 60 $\mathrm{cm}$, pyrolysis zone (T2) at $40 \mathrm{~cm}$, combustion zone (T3) at $25 \mathrm{~cm}$ and reduction zone (T4) at $10 \mathrm{~cm}$ above the gate. In the cases of T5 and T6 thermocouples were located at the inlet and outlet of the gasifier, respectively. All thermocouples were connected with a data logger for recording the temperature profiles and represented the real-time database. When the process entered the steady state condition (observed by a nearly constant temperature), the tests began and experimental data was recorded. All experimental data recorded usedaverage value (three measurements spaced 5 min apart).

\subsection{Experimental Procedure}

The experiment was divided into two parts, the High Temperature Air-Steam Gasification (HTAG) and airsteam gasification (without preheating) compared to the HTAG process. The first part of the experiment began by preheating the temperature of the gasifying agent to a desired level $\left(300,600\right.$ and $\left.900^{\circ} \mathrm{C}\right)$. When the temperature of the gasifying agent was stable, the cassava rhizome charcoal generated from this experiment was fed into the downdraft gasifier to the upper combustion zone level (to avoid tar formation inside the gasifier). Then, the cassava rhizome was fed into the gasifier until fully loaded; afterwards, the gasifier was ignited at the ignition port, which was installed at the combustion zone. Air flow rate, steam flow rate and gasifying agent temperature were operational parameters and were tested in the ranges of 100-300 lpm, 0-6 $\mathrm{kgh}^{-1}$ and $300-900^{\circ} \mathrm{C}$, respectively. Gas sampling, tar sampling and temperature measurements were recorded when the process was in a steady state condition (after 40-50 min). Finally, by-products from the experiment were weighed to calculate the feeding rate $(\mathrm{kg} / \mathrm{h})$. After the HTAG experiment was completed, the air-steam gasification was performed.

\subsection{Investigating Variables Definition}

The steam to biomass ratio (S/B) was calculated by Equation 1:

$\mathrm{S} / \mathrm{B}=\frac{\mathrm{m}_{\text {steam }}}{\mathrm{m}_{\text {feed,dry }}}$

where, $\mathrm{m}_{\text {steam }}$ was the steam feed rate $(\mathrm{kg} / \mathrm{h})$ and $\mathrm{m}_{\text {feed,dry }}$ was the feed rate of feedstock on dry basis $(\mathrm{kg} / \mathrm{h})$.

The Higher Heating Value (HHV) was estimated by Equation 2:

$\mathrm{HHV}=13.1 \times \mathrm{CO}+13.2 \times \mathrm{H}_{2}+41.2 \times \mathrm{CH}_{4}$

where, $\mathrm{CO}, \mathrm{H}_{2}$ and $\mathrm{CH}_{4}$ were the gas concentrations of the producer gas.

The Cold Gas Efficiency (CGE) and the Hot Gas Efficiency (HGE) was calculated by Equation 3 and 4:

$$
\begin{gathered}
\mathrm{CGE}=\frac{\mathrm{HHV}_{\text {gas }} \times \mathrm{m}_{\mathrm{g}}}{\mathrm{HHV}_{\text {feed }} \times \mathrm{m}_{\text {feed,dry }}+\mathrm{E}_{\text {steam }}+\mathrm{E}_{\text {preheat }}} \\
\mathrm{HGE}=\frac{\mathrm{HHV}_{\text {gas }} \times \mathrm{m}_{\mathrm{g}}+\mathrm{E}_{\mathrm{pg}}}{\mathrm{HHV}_{\text {feed }} \times \mathrm{m}_{\text {feed,dry }}+\mathrm{E}_{\text {steam }}+\mathrm{E}_{\text {preheat }}}
\end{gathered}
$$

where, $\mathrm{HHV}_{\text {gas }}$ was the HHV of the producer gas $\left(\mathrm{MJ} / \mathrm{Nm}^{3}\right), \mathrm{E}_{\mathrm{pg}}$ wasthe sensible heat of the producer gas $(\mathrm{MJ} / \mathrm{h}), \mathrm{m}_{\mathrm{g}}$ was the producer gas flow $\left(\mathrm{Nm}^{3} / \mathrm{h}\right)$, $\mathrm{HHV}_{\text {feed }}$ wasthe $\mathrm{HHV}$ of the feedstock $(\mathrm{MJ} / \mathrm{kg})$, $\mathrm{m}_{\text {feed,dry }}$ was thefeed rate of feedstock on dry basis 
$(\mathrm{kg} / \mathrm{h}), \mathrm{E}_{\text {steam }}$ wasthe consumed energy for steam generation $(\mathrm{MJ} / \mathrm{h})$ and $\mathrm{E}_{\text {preheat }}$ wasthe consumed energy for gasifying agent preheating $(\mathrm{MJ} / \mathrm{h})$.

\section{RESULTS AND DISCUSSION}

\subsection{Reduction Temperature}

Gasification is a thermo-chemical process where the temperature plays an important role. The comparison result in the reduction temperatures between the HTAG process and the air-steam gasification (without preheating) were investigated in this section. The preheated temperatures of the HTAG process were examined at 300,600 and $900^{\circ} \mathrm{C}$, respectively. In addition, the $\mathrm{S} / \mathrm{B}$ ratio was changed from 0 to 0.8 while keeping the air supply at $300 \mathrm{lpm}$. The results are presented in Fig. 5.

The results were that temperature changes were similar in all cases, namely, the temperature decreased continuously when the S/B ratio increased. Air-steam gasification and the HTAG process (at 300, 600 and $900^{\circ} \mathrm{C}$ ) have the reduction temperature in the range of $567-742^{\circ} \mathrm{C}(\mathrm{S} / \mathrm{B}$ ratio in the range $0-0.6), 623-796^{\circ} \mathrm{C}$ $(\mathrm{S} / \mathrm{B}$ ratio in the range $0-0.7), 703-871^{\circ} \mathrm{C}(\mathrm{S} / \mathrm{B}$ ratio in the range $0-0.5)$ and $744-902^{\circ} \mathrm{C}(\mathrm{S} / \mathrm{B}$ ratio in the range 0 0.4 ), respectively. The $\mathrm{HTAG}$ process is a process where the gasifying agent (air and steam) was preheated to a high temperature before being fed into the reactor. The sensible heat from preheating improves the thermal energy to the system besides the heat produced from the combustion of oxygen and feedstock only. Therefore, the reduction temperature of the HTAG process is higher than in air-steam gasification which did not have preheating.

\subsection{Gas Composition and Higher Heating Value (HHV)}

$\mathrm{CO}, \mathrm{H}_{2}$ and $\mathrm{CH}_{4}$ are the main combustible gas components in the producer gas and the concentration of those gases have a direct effect on the HHV of the producer gas (estimated by Equation 2). However, it was found that $\mathrm{CO}$ and $\mathrm{H}_{2}$ changed significantly, while $\mathrm{CH}_{4}$ changed very little. In this study, therefore, $\mathrm{CO}$ and $\mathrm{H}_{2}$ were used as variables to compare the HTAG process with the air-steam gasification process. The experiment used $300 \mathrm{lpm}$ of air supply flow while the S/B ratio varied. Figure 6a and $\mathbf{b}$ illustrate the changing concentration of $\mathrm{CO}$ and $\mathrm{H}_{2}$, while Fig. 7 represents the variation of $\mathrm{HHV}$ of the producer gas in each process.
From the experiment results, it can be observed that the $\mathrm{H}_{2}$ concentration (Fig. 6a) obtained from the HTAG process at $900^{\circ} \mathrm{C}$ has a significantly higher volume than the air-steam gasification process in every $\mathrm{S} / \mathrm{B}$ ratio, while the concentration of $\mathrm{H}_{2}$ obtained from the HTAG process at 300 and $600^{\circ} \mathrm{C}$ are in close proximity with the air-steam gasification process $(\mathrm{S} / \mathrm{B}$ ratio range 0.3 0.5). It was found that the $\mathrm{CO}$ concentration (Fig. 6b), at every preheating temperature condition in the HTAG process had a higher volume than in the air-steam gasification process in every $\mathrm{S} / \mathrm{B}$ ratio. As shown in Fig. 7, The HHV of the producer gas from HTAG process at $900^{\circ} \mathrm{C}$ was improved by as much as 5.1 $\mathrm{MJ} / \mathrm{Nm}^{3}$ (at $\mathrm{S} / \mathrm{B}$ ratio $=0.3$ ), while the air-steam gasification, the HTAG at 300 and the HTAG at $600^{\circ} \mathrm{C}$ processes couldonly reach a $\mathrm{HHV}$ of $3.8 \mathrm{MJ} / \mathrm{Nm}^{3}$ (at $\mathrm{S} / \mathrm{B}=0.4$ ), $4.2 \mathrm{MJ} / \mathrm{Nm}^{3}$ (at $\mathrm{S} / \mathrm{B}=0.1$ ) and $4.8 \mathrm{MJ} / \mathrm{Nm}^{3}$ (at $\mathrm{S} / \mathrm{B}=0.2$ ), respectively. Typically, the pyrolysis process is likely to occur at high temperature; therefore, the HTAG process (where the sensible heat from preheating can help to increase the process temperature) has higher volatile product than the airsteam gasification process. This resulted in improved concentrations of combustible gas $\left(\mathrm{CO}, \mathrm{H}_{2}\right.$ and $\left.\mathrm{CH}_{4}\right)$ in the producer gas and the gas flow rate was improved (Lucas et al., 2004; Ponzio et al., 2006). Furthermore, high temperatures can support the endothermic gasification and steam reforming, which resulted in enhanced $\mathrm{CO}$ and $\mathrm{H}_{2}$ concentrations. Therefore, the $\mathrm{HHV}$ of producer gas from HTAG process was higher than in the air-steam gasification process.

\subsection{Tar Content}

In the producer gas during the gasification process, there is an undesirable complex mixture involving heavy hydrocarbons called tar. Tar elimination by thermal cracking (Bui et al., 1994) or by using a catalyst (Ketcong et al., 2009) are widely used methods. Tar can condense at low temperatures, which can lead to clogged gas pipelines and it can adhere on the filters of engines. The variation in tar content obtained from the air-steam gasification process and the HTAG process can be represented in Fig. 8.

As shown in Fig. 8, the changing of tar content in all cases was similar in every condition, namely, the tar content increased continuously with the increasing $\mathrm{S} / \mathrm{B}$ ratio and the lowest tar content was at the no steam injected condition $(\mathrm{S} / \mathrm{B}=0)$ or air gasification. For the HTAG process at $300^{\circ} \mathrm{C}$, the lowest tar content was equal to $277 \mathrm{mg} / \mathrm{m}^{3}$, which was lower than the lowest tar content obtained in the air-steam gasification process $\left(320 \mathrm{mg} / \mathrm{m}^{3}\right)$. 


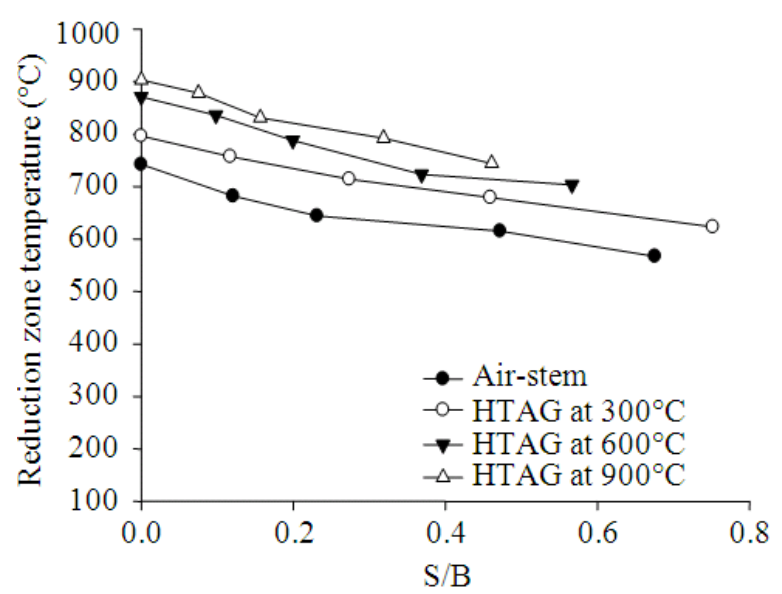

Fig. 5. A comparison of the reduction temperature of the HTAG process with air-steam gasification (At air supply of $300 \mathrm{lpm})$

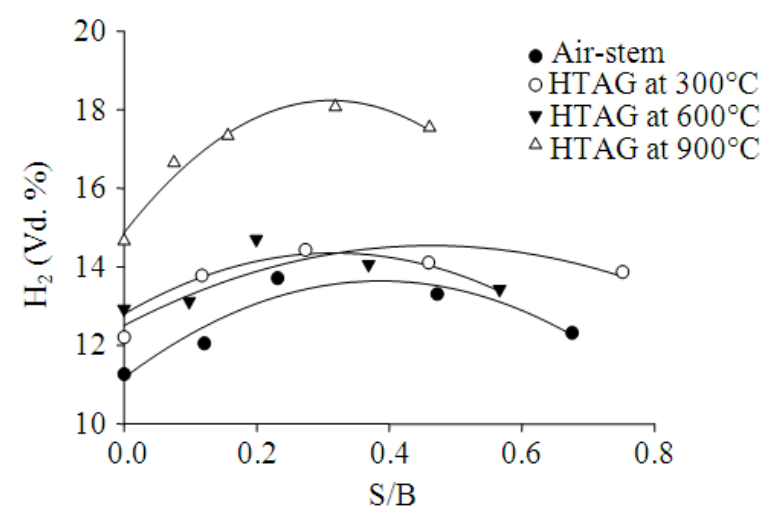

(a) The variation of $\mathrm{H}_{2}$ concentration

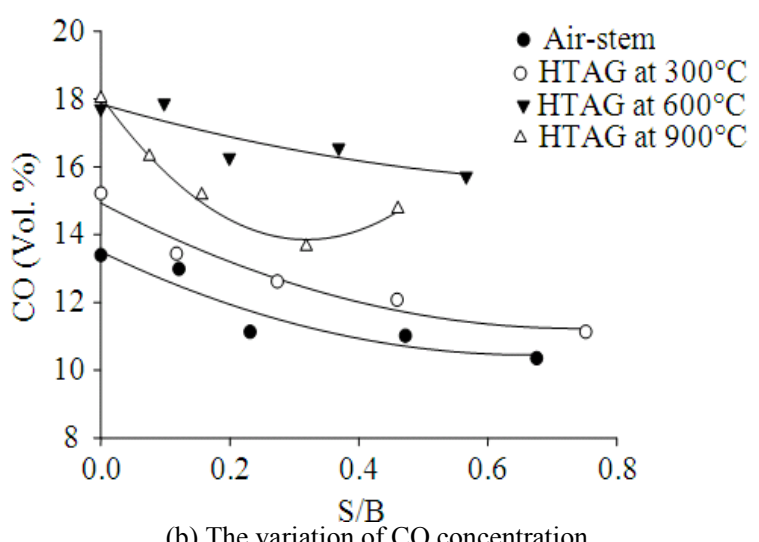

(b) The variation of $\mathrm{CO}$ concentration

Fig. 6. A comparison of $\mathrm{H} 2$ and $\mathrm{CO}$ between the $\mathrm{HTAG}$ and air-steam gasification at air supply of $300 \mathrm{lpm}$

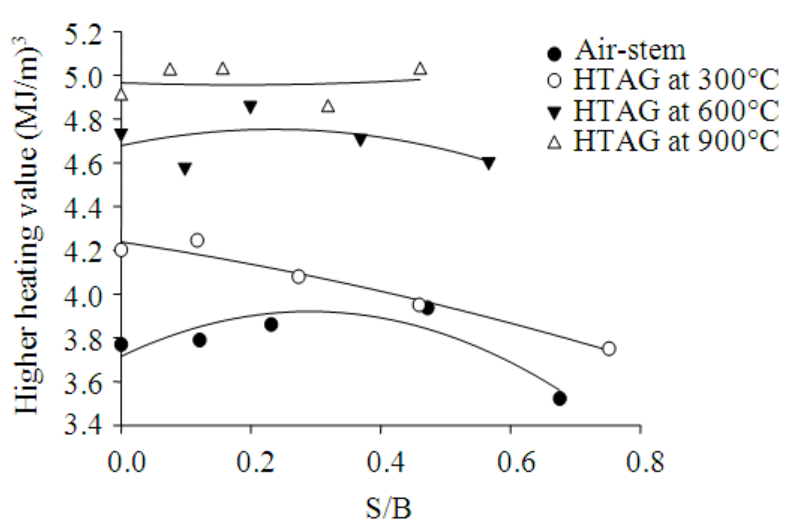

Fig. 7. A comparison of the higher heating value of producer gas between the HTAG process and the air-steam gasification at air supply of $3001 \mathrm{pm}$

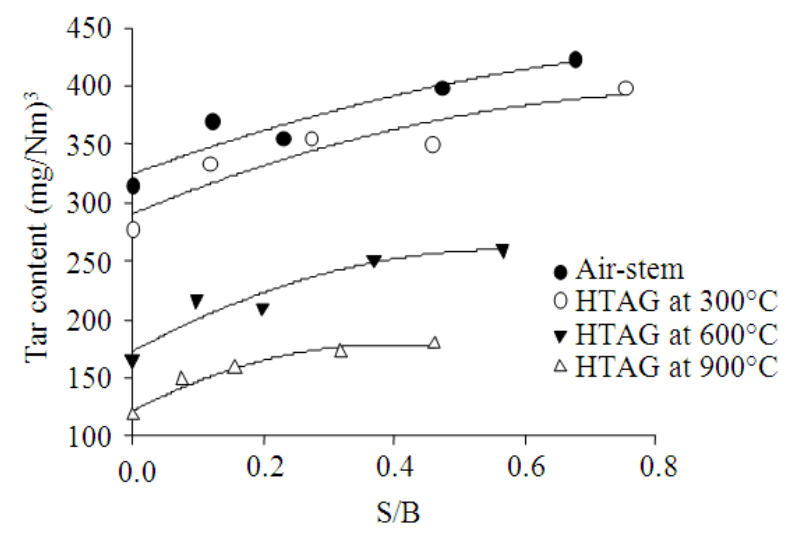

Fig. 8. A comparison of tar content between the HTAG process and air-steam gasification at air supply of $300 \mathrm{lpm}$

In the case of $\mathrm{HTAG}$ at $600^{\circ} \mathrm{C}$ and $\mathrm{HTAG}$ at $900^{\circ} \mathrm{C}$, the lowest tar content was equal to $170 \mathrm{mg} / \mathrm{m}^{3}$ and 95 $\mathrm{mg} / \mathrm{m}^{3}$, respectively. From these results, it can be observed that the lowest tar content from the HTAG process at $900^{\circ} \mathrm{C}\left(95 \mathrm{mg} / \mathrm{m}^{3}\right)$ is lower than the recommended value $\left(100 \mathrm{mg} / \mathrm{m}^{3}\right)$ (Bhattacharya et al., 2001); for use in an Internal Combustion Engine (ICE). The tar content reduction in the HTAG process compared to the air-steam gasification process can be explained by the tar cracking well at higher temperatures (Devi et al., 2003; Li et al., 2009), wherethe gasifier temperature of the HTAG process ismuchhigher than in the air-steam gasification process. Therefore, tar in the HTAG process had more decomposition resulting in decreased tar content. 


\subsection{Cold Gas Efficiency(CGE) and Hot Gas Efficiency (HGE)}

CGE and HGE are important factors to analyze in the economic energy efficiency of the gasifier. CGE is based on the chemical energy from the producer gas and all energy used in the process (calculated by Equation 3). In the case of the HTAG process, the energy used in the process is the summation of the energy from feedstock, energy from steam generation and the energy from the preheated gasifying agent. On the other hand, the HGE is a parameter that considers the benefits of sensible heat energy from the producer gas (calculated by Equation 4). The comparison CGE and HGE of the air-steam gasification and HTAG processes can be shown in Fig. 9.

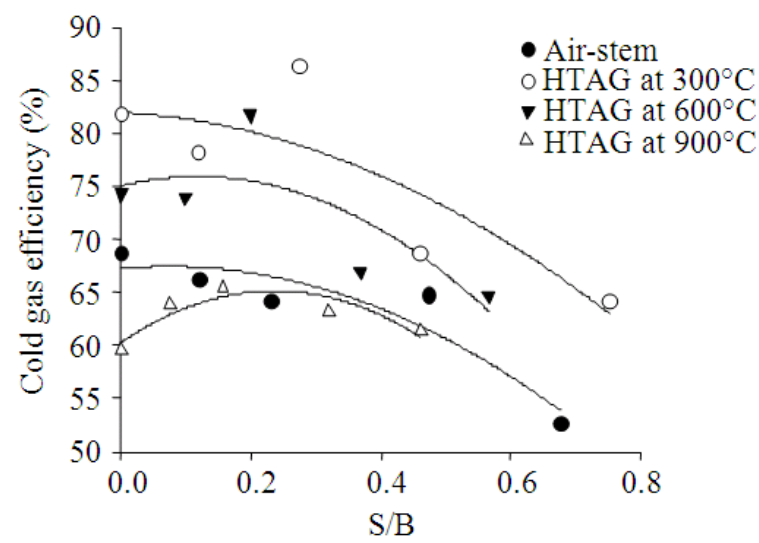

(a)

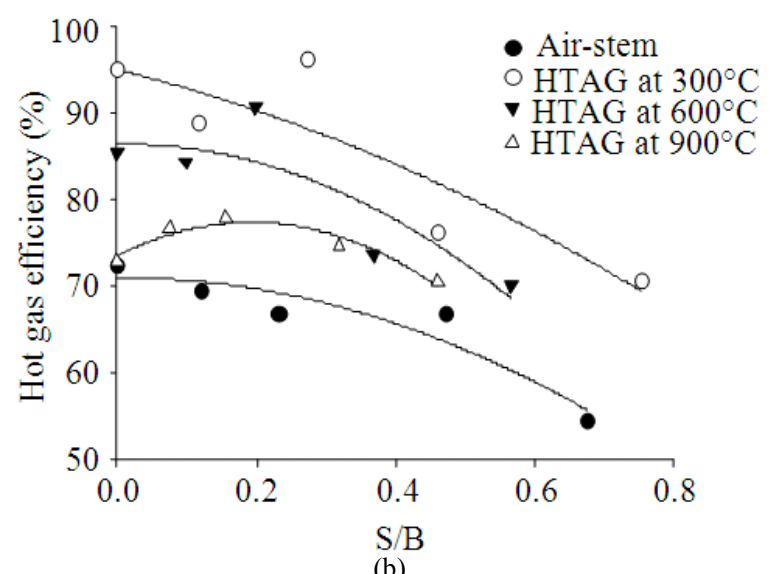

Fig. 9. A comparison of CGE and HGE between HTAG and air-steam gasification at air supply of $300 \mathrm{lpm}$ (a) Cold gas efficiency (b) Hot gas efficiency
As shown in Fig. 9a, the maximum $\mathrm{CGE}$ in the HTAG process at $900^{\circ} \mathrm{C}$ was $65 \%$, which was slightly lower than in the air-steam gasification process $(69 \%)$. The preheating at high temperatures used a lot of energy which resulted in the thermal efficiency of the system being low. However, in the HTAG process at 300 and $600{ }^{\circ} \mathrm{C}$ the maximum CGE increased $24 \%$ (from 69 to $89 \%$ ) and $17 \%$ (from 69 to $81 \%$ ), respectively; compared to the air-steam gasification process. This improvement, can be explained by the HHV of producer gas obtained from the HTAG process being greater than the HHV of the producer gas from the air-steam gasification process and that the HHV value has a direct impact on increasing the $\mathrm{CGE}$; therefore, at 300 and $600^{\circ} \mathrm{C}$ in the $\mathrm{HTAG}$ process, the maximum CGE is more than in air-steam gasification. It was found that in the HTAG process (Fig. 9b), at 300,600 and $900^{\circ} \mathrm{C}$, the maximum HGE increased $33 \%$ (from 72 to $96 \%$ ), 25\% (from 72 to $90 \%$ ) and $7 \%$ (from 72 to $77 \%$ ), respectively; compared to air-steam gasification.

\section{CONCLUSION}

In this study, the High Temperature Air-Steam Gasification (HTAG) process in a downdraft gasifier was investigated. Cassava rhizome was used as feedstock. The quality of producer gas and gasification characteristics were considered. Finally, the results of the HTAG process was compared with the conventional airsteam gasification process (without preheating). The results of this study showed that the reduction temperature in all cases of the HTAG process were higher than in the air-steam gasification in every $\mathrm{S} / \mathrm{B}$ ratio. The $\mathrm{HHV}$ of the producer gas from the HTAG process at $900^{\circ} \mathrm{C}$ was improved by as much as 5.1 $\mathrm{MJ} / \mathrm{Nm}^{3}$ (at $\mathrm{S} / \mathrm{B}$ ratio $=0.3$ ), while the air-steam gasification, $\mathrm{HTAG}$ at 300 and $\mathrm{HTAG}$ at $600^{\circ} \mathrm{C}$ only reached a $\mathrm{HHV}$ of $3.8 \mathrm{MJ} / \mathrm{Nm}^{3}$ (at $\mathrm{S} / \mathrm{B}=0.4$ ), 4.2 $\mathrm{MJ} / \mathrm{Nm}^{3}$ (at $\mathrm{S} / \mathrm{B}=0.1$ ) and $4.8 \mathrm{MJ} / \mathrm{Nm}^{3}$ (at $\mathrm{S} / \mathrm{B}=0.2$ ), respectively. It was found that the tar content of the producer gas obtained from the HTAG process at $900^{\circ} \mathrm{C}$ had the lowest value $\left(95 \mathrm{mg} / \mathrm{m}^{3}\right)$ which could be used as fuel in ICE engines. While the minimum tar content of air-steam gasification was $320 \mathrm{mg} / \mathrm{m}^{3}$. The maximum CGE of the HTAG process at $900^{\circ} \mathrm{C}$ was $65 \%$, which was slightly lower than in the air-steam gasification process $(69 \%)$. However, the benefits of sensible heat from the hot product gas was considered and it can be concluded that in the HTAG process at 300, 600 and 
$900^{\circ} \mathrm{C}$ the maximum $\mathrm{HGE}$ improved $33 \%$ (from 72 to $96 \%$ ), $25 \%$ (from 72 to $90 \%$ ) and $7 \%$ (from 72 to $77 \%$ ), respectively; when compared toair-steam gasification.

\section{ACKNOWLEDGEMENT}

I would like to acknowledge Khon Kaen University and Rajabhat Mahasarakham University for providing the Grant to support this project.

\section{REFERENCES}

Atong, D., P. Sornkade, S. Thassanaprichayanont and V. Sricharoenchaikul, 2011. Fuel generation from catalytic gasification of cassava rhizome. Proceeding of the IET Conference on Renewable Power Generation, Sept. 6-8, IEEE Xplore Press, Edinburgh, pp: 1-6. DOI: 10.1049/cp.2011.0110

Bhattacharya, SC., S.S. Hla and H.L. Pham, 2001. A study on a multi-stage hybrid gasifier-engine system. Biol. Bioenergy, 21: 445-460. DOI: 10.1016/S0961-9534(01)00048-4

Bui, T., R. Roof and S.C. Bhattacharya, 1994. Multistage reactor for thermal gasification of wood. Energy, 19: 397-404. DOI: 10.1016/03605442(94)90118-X

Devi, L., K.J. Ptasinski and F.J.J.G. Janssen, 2003. A review of the primary measures for tar elimination in biomass gasification processes. Biol. Bioenergy, 24: 125-140. DOI: 10.1016/S0961-9534(02)00102-2

Ketcong, A., T. Vitidsant and K. Fujimoto, 2009. The development of ni/dolomite catalyst in simultaneous biomass gasification and reforming in fluidized bed. Am. J. Environ. Sci., 5: 273-277. DOI: 10.3844/ajessp.2009.273.277

Kobayashi, N., M. Tanaka, G. Piao, J. Kobayashi and S. Hatano et al., 2009. High temperature air-blown woody biomass gasification model for the estimation of an entrained down-flow gasifier. Waste Manage., 29: 245-251. DOI: 10.1016/j.wasman.2008.04.014
Li, J., B. Xiao, R. Yan and X. Xu, 2009. Development of a supported tri-metallic catalyst and evaluation of the catalytic activity in biomass steam gasification. Bioresource Technol., 100: 5295-5300. DOI: 10.1016/j.biortech.2009.05.030

Lucas, C., D. Szewczyk, W. Blasiak and S. Mochida, 2004. High-temperature air and steam gasification of densified biofuele. Biol. Bioenergy, 27: 563-575. DOI: 10.1016/j.biombioe.2003.08.015

Lv, P., Z. Yuana, L. Ma, C. Wu and Y. Chen et al., 2007. Hydrogen-rich gas production from biomass air and oxygen/steam gasification in a downdraft gasifier. Renew. Energy, 32: 2173-2185. DOI: 10.1016/j.renene.2006.11.010

Pian, C.C.P. and K. Yoshikawa, 2001. Development of a high-temperature air-blown gasification system. Bioresource Technol., 79: 231-241. DOI: 10.1016/S0960-8524(01)00054-2

Ponzio, A, S. Kalisz and W. Blasiak, 2006. Effect of operating conditions on tar and gas composition in High Temperature Air/steam Gasification (HTAG) of plastic containing waste. Fuel Proc. Technol., 87: 223-233. DOI: 10.1016/j.fuproc.2005.08.002

Tsuji, H., A.K. Gupta, T. Hasegawa, M. Katsuki and K. Kishimoto et al., 2002. High temperature Air Combustion: From Energy Conservation to Pollution Reduction. 1st Edn., CRC Press LLC, ISBN-10: 0849310369, pp: 424.

Umeki, K., K. Yamamoto, T. Namioka and K. Yoshikawa, 2010. High temperature steam-only gasification of woody biomass. Applied Energy, 87: 791-798. DOI: 10.1016/j.apenergy.2009.09.035 